\title{
Riparian Review
}

\section{Home study course makes riparian management techniques available in written/video format.}

\author{
By Sandra Wyman and Gene Surber
}

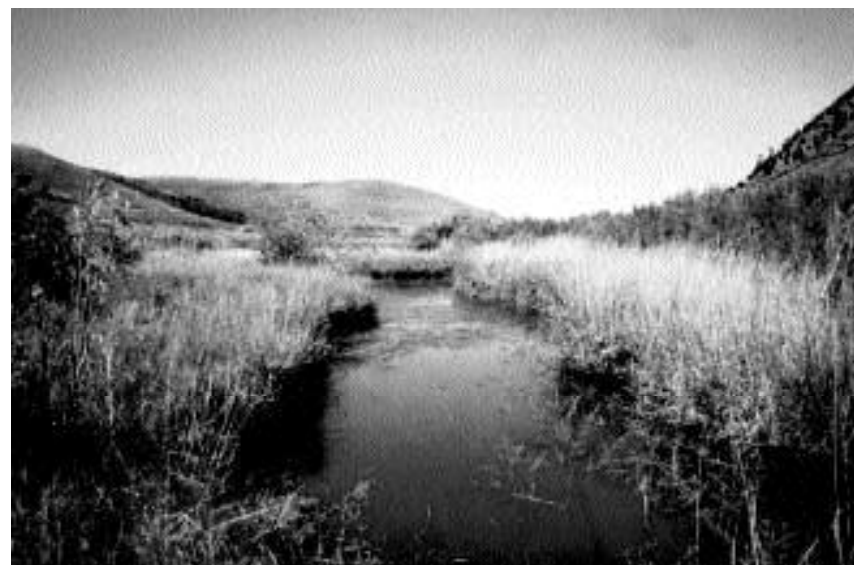

$\mathrm{M}$ anagers who make use of riparian areas as part of their grazing resource have an enjoyable and convenient way to learn effective riparian grazing management concepts through the use of a "home study" educational course. The course, called "Stream and Riparian Area Management: A Home Study Course for Managers," was produced by Gene Surber, Extension Natural Resources Specialist, at Montana State University, and Bob Ehrhart, former Riparian Research Associate, Riparian Wetland Research Program, at the University of Montana.

Good stream and riparian management is important to producers for several reasons:

- Riparian areas are among the most productive parts of any ranch. They are, in fact, prime examples of "renewable resources" because water and nutrients make them especially resilient.

- On many ranches, the streams that flow through riparian areas are the major source of livestock water. The riparian area has an influence on the quality and quantity of available water.

- Riparian areas, including woody draws, can provide essential shelter for livestock.

- Riparian management is an essential part of good land stewardship because healthy riparian areas are critical to healthy lanscapes.
The course aims to help producers realize that effectively managing grazing animals in and around riparian areas requires understanding the dynamics of riparian areas. It also offers techniques that may be used to enhance their function.

As important as riparian areas are, however, they are not a separate, isolated part of any livestock operation. Implicit in this home study course is the principle that managing riparian areas can only be effective if it's done within the context of an entire operation.

A survey of managers who have used the course materials indicates $60 \%$ of them have modified their management following use of the materials.

\section{What Does The Course Include?}

Developed to assist busy landowners, the home study course includes a full color workbook with more than 80 pictures, four videos ranging in length from 16 to 22 minutes and 12 supplemental reference materials. Some of these materials are referred to in the written lessons and the videos.

This material is built around several questions that will help managers design a plan:

- What do we have and how well is it working?

- What do we want to have? What do we want our riparian areas and streams to look like?
- How will we get where we want to be?

- How will we know if we're heading in the right direction?

Because each ranch and operation is different, managers will find different answers to these questions based on the lands they manage.

The course is divided into four sections:

1) Streams and Watersheds

2) Riparian Areas: Function and Condition

3) Grazing Management for Healthy Riparian Areas

4) The Riparian Area Management Plan.

Each section includes a written lesson in the workbook and accompanying video. The material gives a broad overview of the form and function of streams and riparian areas plus describes principles and techniques that can be affected through management. Examples of items described in the written materials are shown in the accompanying video.

The last section of the course assists land managers in the development of a grazing management plan based on an inventory of resources they have collected at the completion of each of the previous sections. The"final exam" will be the development of a riparian grazing plan for a ranch. 
The plan should reflect these key points:

1. To be successful, riparian grazing must be based on clearly defined and measuable goals and incorporated into the overall ranch operations.

2. Riparian grazing strategies are most successful when they are designed for a specific area, and, most of all, are flexible.

3. Determining the effectiveness of management actions and identifying the need for modification are best done with a planned, systematic monitoring program.

Photo description top right page 22; Riparian areas are the link between the water and the uplands.

Authors are Rangeland Management Specialist, Natural Resources Conservation Service, Bozeman, MT and Extension Natural Resources Specialist, Montana State University, Bozeman, MT, respectively.

\section{How To Get The Course}

The Society for Range Management Watershed/Riparian Committee believes that this course is appropriate for use by SRM Sections for their high school youth activities. The committee received EPA funding to distribute a copy of the video course to each SRM Section and to the majority of $\mathrm{Ag}$ in the Classroom state coordinators.

Contact your SRM Section President or Ag in the Classroom representative to view this course. The workbook portion of the course may be viewed on the web at: www.hornepage.montana.edub.-stream/. Hard copies of the workbook and videos may be ordered at this site. Copies of the course may also be purchased from:

MSU Extension Publications

P.O. Box 172040

Bozeman, MT 59717-2040

Credit card orders (406) 994-3273

Comments, suggestions and questions are always welcome. Directly contact: Gene Surber, Extension Natural Resources Specialist, Rm. 217 Linfield Hall, Montana State University Bozeman, MT 59717; (406) 994-1971 gsurber@.montana. edu; or

Bob Ehrhart, Associate Professor of Rangeland Resources, COCC/Ponderosa 215, 2600 NW College Way; Bend, OR 97701-5998; (541)312-8503

bob. ehrhart@orst.edu

\section{Rates for Advertising in SRM Publications}

\author{
Mechanical Requirements \\ Press: \\ Screen: \\ sheetfed offset \\ Materials: \\ up to 120 \\ right-reading negatives, \\ Camera-ready artwork, e-mail or disks save \\ as jpegs or tiff files \\ Columns: $\quad$ pages have 2 columns of $31 / 2$ inches wide \\ and $91 / 2$ inches deep \\ Color: \\ black \& white (inquire for additional \\ color information)
}

$\begin{array}{cc}\text { Rates for JRM and Rangelands } & \\ \text { Inside Front Cover }(81 / 2 \times 11) & \$ 800 \\ \text { Inside Back Cover }(81 / 2 \times 11) & \$ 720 \\ \text { Full Page Bleed }(81 / 2 \times 11) & \$ 660 \\ \text { Full Page }(81 / 2 \times 91 / 2) & \$ 600 \\ 2 / 3 \text { Page }(71 / 8 \times 91 / 2) & \$ 420 \\ 1 / 2 \text { Page }(31 / 2 \times 9 / 2) & \$ 320 \\ 1 / 3 \text { Page }(31 / 2 \times 7) & \$ 200 \\ 1 / 4 \text { Page }(31 / 2 \times 43 / 4) & \$ 160 \\ 1 / 8 \text { Page }(31 / 2 \times 23 / 8) & \$ 80 \\ 1 \text { column inch }(31 / 2 \times 1) & \$ 40\end{array}$

$\begin{array}{ll}\begin{array}{l}\text { Rates for Trail Boss News } \\ \text { Full Page }(81 / 2 \times 11)\end{array} & \$ 300 \\ 2 / 3 \text { Page }(71 / 8 \times 91 / 2) & \$ 210 \\ 1 / 2 \text { Page }(31 / 2 \times 91 / 2) & \$ 160 \\ 1 / 3 \text { Page }(31 / 2 \times 7) & \$ 100 \\ 1 / 4 \text { Page }(31 / 2 \times 43 / 4) & \$ 80 \\ 1 / 8 \text { Page }(31 / 2 \times 23 / 8) & \$ 40 \\ 1 \text { column inch }(31 / 2 \times 1) & \$ 20\end{array}$

\section{General Information:}

Cancellations cannot be accepted for any of the publications after the closing date.

All advertising copy is subject to SRM approval

\section{Deadline Dates}

The Trail Boss News is noon on the first of the month it is to be published in. Deadline dates for the JRM and Rangelands are the 1st of the month prior to their publication, i.e. October Rangelands ads need to be received by September 1 . 